\title{
ПРОБЛЕМНІСТЬ - ШЛЯХ ДО АКТИВІЗАЦІЇ НАВЧАННЯ СТУДЕНТІВ ЗІ СПЕЦАЛЬНИХ дИСЦИПЛІн
}

\begin{abstract}
Розглянуто проблемне навчання як шлях активізачії діяльності студентів. Визначені та узагальнені особливості методики навчання спеціальних дисциплін: методичні особливості лекцій, практичних занять, семінару, самостійноі роботи на прикладі спеціальної дисципліни «Кормовиробництво».

Ключові слова: проблемне навчання, активізачія навчання, розігрування ролей, часткова методика.

Рассмотрено проблемное обучение как путь активизации деятельности студентов. Определены и обобщены особенности методики обучения специальных дисциплин: методические особенности лекций, практических занятий, семинара, самостоятельной работы на примере спечиальной дисчиплины «Кормопроизводство».

Ключевые слова: проблемное обучение, активизачия обучения, разыгрывание ролей, частичная методика.
\end{abstract}

The considered problem study as a way of activization of activity of students. The certain and generalized features of a technique of study of special disciplines: methodical features of lectures, practical occupations, a seminar, independent work by the example of special discipline.

Key words: problem study, activization of study, playing of roles, a partial technique.

Компонентами проблемної ситуації є: об'єкт пізнання (матеріал лекції) і суб'єкт пізнання (студент), процес розумової взаємодії суб'єкта 3 об'єктом є пізнавальною діяльністю, засвоєння нового, невідомого ще для студента знання, що міститься в навчальній проблемі.

Навчальні проблеми повинні бути доступними за рівнем складності для студентів, мають ураховувати пізнавальні можливості тих, хто навчається, виходити з предмета, що вивчається, і бути значущими для засвоєння нового матеріалу і розвитку особи - загального і професійного [1-6].

Навчальна проблема й система супідрядних підпроблем, складених викладачем до лекції, розгортається під час лекції у навчальному мовленні викладача. В умовах проблемної лекції відбувається усний виклад матеріалу діалогічного характеру [1].

За допомогою відповідних методичних прийомів (постановка проблемних та інформаційних запитань, висунення гіпотез і їх підтвердження або спростування, звернення до студентів по допомогу тощо) викладач спонукає студентів до сумісного роздуму, дискусії, яка може розпочатися безпосередньо на лекції або на наступному семінарі [2, с. 6].

Чим вищим є етап діалогічності лекції, тим більше вона наближається до проблемної і тим вищі їі орієнтувальний, навчальний і виховний ефекти. I, навпаки, чим більше лекція наближається до монологічного викладу, тим більшою мірою вона наближається до інформаційної.

Метою статmi є розглянути проблемне навчання як шлях активізації діяльності студентів зі спеціальних дисциплін.

Проблемна лекція починається з питань, із постановки проблеми, яку в ході викладу матеріалу необхідно розв'язати. Проблемні запитання відрізняються від непроблемних тим, що прихована в них проблема вимагає неоднотипного розв'язання, тобто готової схеми розв'язання в минулому досвіді немає [1].

За допомогою проблемної лекції забезпечується досягнення трьох основних дидактичних цілей: 1) засвоєння студентами теоретичних знань; 2) розвиток теоретичного мислення; 3) формування пізнавального інтересу до змісту навчальної дисципліни і професійної мотивації майбутнього фахівця.

Успішність досягнення мети проблемної лекції забезпечується взаємодією викладача і студентів. Основне завдання викладача полягає не тільки в передачі інформації, а в залученні студентів до об'єктивних суперечностей розвитку наукового знання, що формує мислення студентів, спонукає їх до пізнавальної активності. У співпраці з викладачем студенти отримують нові знання, осягають теоретичні особливості своєї професії [2].

Педагог повинен використовувати під час лекції такі засоби спілкування, які забезпечують найефективнішу передачу самої особи педагога, оскільки чим ближче педагог до зразка професіонала, тим більший є вплив викладача на студентів і тим ефективнішими є результати навчання.

На проблемній лекції у спільній діяльності викладача і студентів досягається мета загального і професійного розвитку особи фахівця.

На відміну від змісту інформаційної лекції, що пропонується викладачем у вигляді відомого, лише для запам'ятовування матеріалу, на проблемній лекції нове знання вводиться як невідоме для студентів. Одержана інформація засвоюється як особисте відкриття ще невідомого для себе знання, що дозволяє створити у студентів ілюзію «відкриття» вже відомого в науці. Проблемна лекція будується таким чином, що пізнання студента наближаються до пошукової, дослідницької діяльності. 
За цієї ситуації беруть участь мислення студента і його особове ставлення до засвоюваного матеріалу [4].

Протягом лекції мислення студентів відбувається за допомогою створення викладачем проблемної ситуації до того, як вони одержать всю необхідну інформацію, що становить для них нове знання. У традиційному навчанні - навпаки - спочатку дають знання, спосіб або алгоритм вирішення, а потім приклади, на яких можна повправлятися в застосуванні цього способу. Таким чином, студенти самостійно пробують знайти вирішення проблемної ситуації.

Отже, лекція стає проблемною в тому випадку, коли в ній реалізується принцип проблемності. При цьому необхідним $€$ виконання двох взаємозв'язаних умов: 1) реалізація принципу проблемності при відборі й дидактичному обробленні змісту навчального курсу до лекції; 2) реалізація принципу проблемності при розгортанні цього змісту безпосередньо на лекції [6].

Перше досягається за рахунок розроблення викладачем системи пізнавальних задач - навчальних проблем, що відображають основний зміст навчальної дисципліни; друге - побудовою лекції як діалогічного спілкування викладача зі студентами.

Діалогічне спілкування може будуватися як живий діалог викладача зі студентами під час лекції на тих етапах, де це доцільно, або як внутрішній діалог (самостійне мислення), що найбільш типове для лекції проблемного характеру. У внутрішньому діалозі студенти разом із викладачем ставлять питання і відповідають на них або фіксують питання в конспекті для подальшого з'ясування під час самостійних завдань, індивідуальної консультації 3 викладачем або ж обговорення 3 іншими студентами, а також на семінарі.

Діалогічне спілкування $є$ необхідною умовою для розвитку мислення студентів, оскільки за способом свого виникнення мислення діалогічне.

Стиль спілкування викладача на проблемній лекції: 1) викладач входить у контакт з студентами не як «законодавець», а як співрозмовник; 2) викладач не тільки визнає право студента на власну думку, але і зацікавлений у ній; 3) нове знання набуває статусу істинного не тільки через авторитет викладача, вченого або автора підручника, але і через доказ його істинності системою міркувань; 4) матеріал лекції включає обговорення різних поглядів на розв'язання навчальних проблем, відтворює логіку розвитку науки, іï змісту, показує способи вирішення об’єктивних протиріч в історії науки; 5) спілкування зі студентами будується так, щоб підвести їх до самостійних висновків, зробити співучасниками процесу підготовки, пошуку і знаходження шляхів розв'язання протиріч, створених самим же викладачем; 6) викладач будує запитання до матеріалу, що вводиться, i відповідає на них, викликає запитання у студентів і стимулює самостійний пошук відповідей на них під час лекції [4].

Здібність до самостійного мислення формується у студентів під час активної участі в різних формах живого мовного спілкування. Для цього лекції проблемного характеру необхідно доповнювати семінарськими заняттями - дискусіями і діалогічними формами самостійної спільної роботи студентів [5].

Для управління мисленням студентів на проблемній діалогічній лекції використовуються наперед складені викладачем проблемні й інформаційні запитання.

За допомогою поєднання проблемних та інформаційних питань викладач може враховувати і розвивати індивідуальні особливості кожного студента.

Вимоги до запитань на проблемній лекції: 1) у питанні відображається результат попереднього розумового аналізу умов розв'язання задачі, відділення зрозумілого від незрозумілого, відомого від невідомого; 2) вказується на завдання і напрям пошуку невідомого у проблемній ситуації (наприклад, невідомий поки студентам спосіб аналізу умов, вирішення задачі тощо); 3) невідоме ставиться на структурне місце мети пізнавальної діяльності студентів і тим самим виявляється чинником управління цією діяльністю; 4) є засобом залучення студента в діалогічне спілкування, у спільну 3 викладачем розумову діяльність щодо знаходження шляхів розв'язання пізнавальної задачі.

Проблемні лекції забезпечують творче засвоєння майбутніми фахівцями принципів i закономірностей науки, що вивчається, активізують навчально-пізнавальну діяльність студентів, їх самостійну аудиторну й позааудиторну роботу, засвоєння знань і застосування їх на практиці [5].

Викладач ставить перед студентами запитання проблемного характеру: «Чому доцільні спільні посіви конюшини лугової з тимофіївкою луговою, овсянницею луговою, кострецем безостим, райграсом пасовищним та іншими видами, хоча на таких посівах другого року життя трав переважає насіння конюшини лугової?» і разом із студентами визначає шляхи його розв'язання.

Педагог пропонує провести практичне заняття на приклді питання плану «Багаторічні бобові трави», використовуючи значний обсяг ілюстрованого матеріалу та табличних даних. Викладач ставить завдання у вигляді виробничих ситуацій, звертаючись до освітньо-кваліфікаційної характеристики: 1) ознайомлення з морфологічними ознаками багаторічних трав - «Як дипломований фахівець, дайте консультацію практикантам щодо морфологічних ознак багаторічних трав»; 2) ознайомлення 3 технологією вирощування багаторічних кормових трав - «Як фахівець із кормовиробництва, визначте особливості технології вирощування багаторічних кормових трав»; 
викладач розглядає найпоширеніші у лісостеповій зоні багаторічні кормові трави, використовує мультимедійні технології, роздатковий матеріал (посібники, інструкції), гербарії [2, с. 3].

Викладач пропонує провести вивчення питання плану «Багаторічні малопоширені кормові культури» у вигляді аудиторної самостійної роботи. Він актуалізує тему, а саме: серед кормових культур є значна кількість таких, що не набули поширення. Причиною цього є недостатнє вивчення їх дії на продуктивність, здоров'я тварин, відтворення поголів'я. Знання хімічного складу i продуктивності культур недостатньо для їх об'єктивної оцінки. Друга причина полягає у відсутності насіння. Має значення також певний консерватизм в інтродукції нових культур. Відіграє роль і недостатня опрацьованість технології вирощування [3].

Викладач активізує знання студентів, формулюючи запитання проблемного характеру: «Чому такі високобілкові багаторічні культури, як борщівник Сосновського, спориш Вейріха, сільфія пронизанолиста, рапонтик (маралячий корінь), живокіст шорсткий, в Україні і донині $\epsilon$ малопоширеними?».

Акцентується увага на тому, що серед малопоширених багаторічних культур - борщівник Сосновського, спориш Вейриха, сільфія пронизанолиста, рапонтик (маралячий корінь), живокіст шорсткий - високобілкові культури. Іх використовують переважно для заготівлі силосу. Іноді ці культури називають новими. Насправді вони не нові, оскільки їх вивчали у BIP ще в повоєнний період. У 1947 р. їх детально описав П. Медведєв. Широко відомі дослідження кафедри рослинництва Московської сільськогосподарської академії, Інституту землеробства УААН та інших дослідних установ і ВНЗ із вивчення нетрадиційних кормових культур.

Викладач узагальнює й систематизує відповіді студентів та роздає індивідуальні завдання, які містять виробничі ситуації та стосуються морфо-біологічних особливостей культур [3].

Методичні особливості навчання теми «Багаторічні кормові культури»: 3 культурами студенти добре обізнані, тому доцільне проблемне навчання матеріалу другого рівня проблемності (студенти разом з викладачем шукають шляхи розв'язання запитання проблемного характеру). Інструктажі, застосування мультимедійних засобів навчання, виробничі завдання відповідно до освітньокваліфікаційної характеристики фахівця. Наявність роздаткової літератури, гербарію; індивідуалізоване навчання - завдання виробничого характеру; запитання проблемного характеру під час активізації знань студентів і заключного інструктажу та евристична бесіда, рейтингове оцінювання.

Викладач пропонує провести лекцію з теми «Методика навчання теми «Капустинні (хрестоцвітні) кормові культури» у формі семінарського заняття: тема актуальна, але студенти ознайомленні 3 нею мало. Він наголошує на актуалізації теми, вказуючи на ії значення для майбутньої практичної діяльності студентів. Педагог нагадує завдання до семінару, адже до нього студенти готуються за отриманими на лекції завданнями. Семінар включає питання з утрудненнями з лекцій, практичних занять та позааудиторної роботи (запитання для самоконтролю). Викладач проводить заняття у формі реферативних повідомлень (з власною оцінкою проблеми) та евристичної бесіди (викладач ставить студентам запитання проблемного характеру) [3].

Підводяться підсумки роботи на семінарі та узагальнюється й систематизується матеріал, оскільки домінуючими методами на лекції були: проблемне викладення, евристична бесіда.

Викладач проводить лекцію з елементами проблемності (другого та третього рівнів) - культури (кормові корнеплоди) студентам добре знайомі 3 власного досвіду і $з$ дисципліни «Рослинництво» $\mathrm{i}$ мають поширене застосування у кормовиробництві. Особливість організації лекції - можливий аналіз виробничих ситуацій із розподілом ролей відповідно до освітньо-кваліфікаційної характеристики фахівців [3].

Пропонується також провести лекцію 3 теми «Методика навчання теми «Проміжні посіви польових культур» 3 елементами проблемності (третього рівня). Основна увага буде звертатися на реалізацію виховної мети - розглядається культура конопля. Використання мультимедійних засобів навчання: порівняння здорового способу життя та господарське значення коноплі 3 картинками про можливі наслідки нездорового способу життя.

Звертається увага на вміння майбутніх фахівців - керівників середньої ланки - своїм прикладом здорового способу життя позитивно впливати на оточуючих. Студентам ставиться запитання проблемного характеру: «Чому конопля, як важлива проміжна польова культура, не набула поширення в Україні?». Вони самостійно шукають відповідь на запитання під час повідомлення викладачем наукових фактів із теми. Евристична бесіда, як домінуючий метод, є структурно формувальною лекційного заняття. Для цього викладач повинен мати в педагогічній скриньці додаткові запитання проблемного характеру, які допоможуть йому спрямувати студентів у правильне русло.

Обов'язковим елементом проблемного викладення матеріалу $\epsilon$ його узагальнення та систематизація.

Методичні особливості навчання теми: проблемне навчання матеріалу передбачає рейтингове оцінювання: заохочувальні бали; евристична бесіда, як домінуючий метод, визначає попередню підготовку викладачем запитань проблемного характеру та виробничих ситуацій. 
Викладач пропонує провести лекцію 3 теми «Методика навчання теми «Кормові сівозміни та зелений конвеєр» у формі рольової гри: розігрується обласна нарада керівників середньої ланки запитання формулюються як план лекції. Тому актуалізацію теми (виголошення проблемного запитання), активізацію діяльності студентів (налагодження міжпредметних зв'язків) викладач проводить у ролі керівника обласної ланки для керівників районних підрозділів - студентів. Мультимедійні засоби навчання сприятимуть розкриттю теми [3].

Підводяться підсумки рольової гри, оцінюється діяльність студентів за рейтинговою шкалою, висловлюється подяка студентам за співпрацю.

Методичні особливості навчання теми: розігрування ролей на лекції передбачає такий вид заняття, як лекція вдвох (запрошується викладач спорідненої дисципліни).

Отже, проблемна лекція будується так, щоб зумовити по- яву питання у свідомості студента. Навчальний матеріал представляється у формі навчальної проблеми. Вона має логічну форму пізнавальної задачі, що відзначає деякі суперечності в ії умовах і завершується питаннями, які ця суперечність об'єктивує. Проблемна ситуація виникає після виявлення суперечностей в початкових даних навчальної проблеми. Для проблемного викладу відбираються найважливіші розділи курсу, які складають основний концептуальний зміст спеціальної дисципліни, $\epsilon$ найважливішими для майбутньої професійної діяльності і найскладнішими для засвоєння студентами.

Педагогічна ефективність лекцій, інтерес до них визначається також застосуванням допоміжних засобів - демонстрацією експерименту, наочністю, використанням мультимедійних засобів навчання. Література

1. Гончаренко С. У. Методика як наука / С. У. Гончаренко. - К. : Либідь, 2000. - 156 с. 2. Журавська Н. С. Методологія і методика НОП / Н. С. Журавська. - Ніжин : Видавець ПП М. М. Лисенко, 2012. - С. 98-10. 3. Журавська Н. С. Методика навчання дисципліни «Кормовиробництво»/ Н. С. Журавська. - Ніжин : Видавець ПП М. М. Лисенко, 2012. - С. 83-92. 4. Журавська Н. С. Теорія і методика професійного навчання / Н. С. Журавська. - Ніжин : Видавець ПП М. М. Лисенко, 2011. - С. 74-85. 5. Журавська Н. С. Теорія і практика підготовки викладачів аграрних дисциплін у вищих навчальних закладах країн Європейського Союзу : [ монографія] / Н. С. Журавська. - Ніжин : Видавець ПП М. М. Лисенко, 2011. - 320 с. 6. Журавська Н. С. Підготовка викладачів-аграрників у вищих навчальних закладах країн Європейського Союзу (Франція, Німеччина, Бельгія, Італія, Люксембург, Нідерланди і Великобританія) : [монографія] / Н. С. Журавська. Ніжин : Видавець ПП М. М. Лисенко, 2009. - 345 с. 